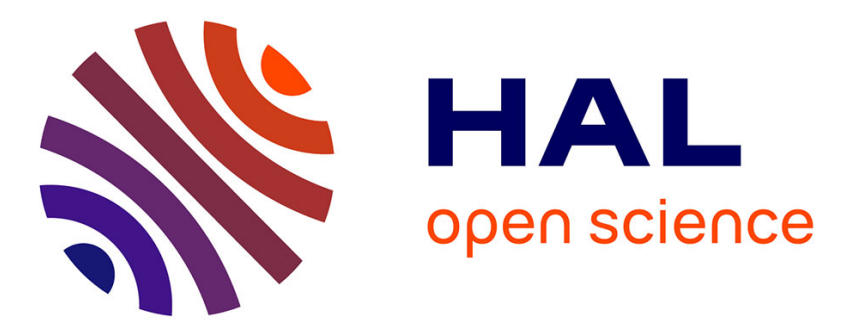

\title{
Mechanical properties of Glued-laminated timber made up of mixed tropical wood species
}

Arnauld Clauvy'S Engonga Edzang, Claude Feldman Pambou Nziengui, Serge Ekomy Ango, Samuel Ikogou, Rostand Moutou Pitti, Cédrick Horphé Ndong Bidzo

\section{To cite this version:}

Arnauld Clauvy'S Engonga Edzang, Claude Feldman Pambou Nziengui, Serge Ekomy Ango, Samuel Ikogou, Rostand Moutou Pitti, et al.. Mechanical properties of Glued-laminated timber made up of mixed tropical wood species. Wood Material Science and Engineering, 2021, pp.1-14. 10.1080/17480272.2021.1960422 . hal-03468187

\section{HAL Id: hal-03468187 \\ https://hal.science/hal-03468187}

Submitted on 6 Dec 2021

HAL is a multi-disciplinary open access archive for the deposit and dissemination of scientific research documents, whether they are published or not. The documents may come from teaching and research institutions in France or abroad, or from public or private research centers.
L'archive ouverte pluridisciplinaire $\mathbf{H A L}$, est destinée au dépôt et à la diffusion de documents scientifiques de niveau recherche, publiés ou non, émanant des établissements d'enseignement et de recherche français ou étrangers, des laboratoires publics ou privés.

\section{(이)(\$)}

Distributed under a Creative Commons Attribution - NonCommercial - NoDerivatives| 4.0 


\title{
Comparative studies of three tropical wood species under compressive cyclic loading and moisture content changes
}

\author{
Arnauld Clauvy's ENGONGA EDZANG ${ }^{1}$, Claude Feldman PAMBOU NZIENGUI ${ }^{1,2,4}$, Serge \\ EKOMY ANGO ${ }^{3}$, Samuel IKOGOU ${ }^{4}$, Rostand MOUTOU PITTI ${ }^{2,3}$, \\ ${ }^{1}$ Ecole Nationale des Eaux et Forêts, LaReVa Bois, BP 3960 Libreville, Gabon \\ ${ }^{2}$ Université Clermont Auvergne, CNRS, SIGMA Clermont, Institut Pascal, BP 10448, 63000 \\ Clermont-Ferrand, France \\ ${ }^{3}$ CENAREST, IRT, BP 14070, Libreville, Gabon \\ ${ }^{4}$ USTM, Ecole Polytechnique de Masuku, BP 901 Franceville, Gabon
}

\begin{abstract}
This paper deals with the experimental study devoted to cyclic compressive loading of three tropical species (Aucoumea Klaineana Pierre AKP, Milicia Excelsa ME and Pterocarpus Soyauxii PS) at different moisture content levels. According to the French requirement NF EN 408, 90 samples taken from these three species were dimensioned. The experimental campaign is compounded of static tests concerning 15 samples and cyclic tests performed on 75 samples. First, the samples are loaded into the static compressive test until their collapse, in order to obtain the mechanical characteristics of each species in terms of: (i) the modulus of elasticity, (ii) the maximal strength and (iii) the stress at the yield point. Then, each sample is loaded five times in cyclic compressive loading, following the paths of loading-unloading-reloading, at different moisture contents levels. The maximal load applied for each cycle corresponds to $10 \%$ of the collapse load of the AKP species. The results show a stiffening of the samples with the loading cycles. The stiffening is faster from the densest species to the least dense species, respectively. In addition, the phenomenon of densification, that occurs during the five loading cycles, is done with constancy of compressive strength in the three species.
\end{abstract}

Keywords: Tropical species; Effect of moisture content; cyclic compressive loading; compressive static tests. 


\section{Introduction}

These last years, there are had a growing interest in the use of wood in the timber structures industry (Natterer 2004, Stevens 1990), this observation is valid for all the regions around the world (Kitek Kuzman and Sandberg 2018). In Gabon for example, this involved the valorisation and the harvesting of new types of wood species by reducing the pressure put into Aucoumea Klaineana Pierre $(A K P)$. In fact, APK appears today, with over $90 \%$ of the annual national production, as the most specie harvested and the most exploited. Indeed, in this country, during the 20th century, the production of $A K P$ continued to increase with the continuous improvement of the wood machinery (pulling machine, dryer,...) and the increased harvesting surface areas (Medzegue et al. 2007, Peyrot 2008). In terms of volume in 2018, log production increased by $6 \%$ to more than 1.27 million $\mathrm{m}^{3}$, compared with 1.2 million $\mathrm{m}^{3}$ in September 2017. However, from the 1960s, we saw harvesting of new types of species called diverse woods. Among these species we have: Milicia Excelsa ME (so called Iroko) and Pterocarpus Soyauxii PS (Peyrot 2008, Mertens et al. 2007). The literature (Pambou Nziengui et al. 2017, Odounga et al. 2018) shows that these kind of species at $12 \%$ of the moisture content, for example, offer the better physical and mechanical properties as the $A K P$. So, for a better understand of their mechanical behaviour and their use in construction it is necessary to study them under complex mechanical loading and conditions. It is known that wood is a material whose mechanical properties (elastic, viscous, failure,...) are related to the conditions of environmental parameters such as the relative humidity and temperature (Eurocode 12005 , Moutee 2006, Gerhards 1982, Ebrahimzadeh and Kubat 1993). This dependency is often linked with the variations of its moisture content and the intensity of the load applied (Mårtensson and Thelandersson 1990, Lenth and Kamke 2001, Moutee et al. 2005, Mukudai and Yata 1986, Navi and Girardet 2000). In the same case, the works of Gerhards (1982) show that many of the mechanical properties of wood reduce when its moisture content goes from $12 \%$ to $20 \%$, below the fibre saturation point (FSP). These results have been also related by Guitard et al. (1987), through its analytical model to predict the module of elasticity for example which taking into account the variations of moisture content and the density of the sample studied. In addition, the interaction of moisture changes with mechanical loads can lead to excessive strains in wood structures (Redman et al. 2016, Manfoumbi Boussougou et al. 2014). Both precedent examples describe sufficiently the influence of moisture on the mechanical behaviour of wood material in structures.

The literature review shows also that the stresses on wood materials and timber structures are mainly due to the combined actions of mechanical and environmental effects (Eurocode 12005 , Moutee 2006, Eurocode 5 2005). In fact, there are very specific processes used to describe the laws of mechanical behaviour of wood in interaction with environmental factors. Among these processes, we have different tests such as creep, bending, tensile, compression, torsion and shear tests. The aim of the use of these processes is to highlight the stress-strain relationships of the material tested. To these tests, we can add the cyclic tests, characterized by a mode of fatigue breakage which is just as important but rarely studied, especially on wood material (Pambou Nziengui et al. 2017, Nafa and Araar 2003), and even less so on tropical species. Also, Pambou and al. (2017) highlighted the study on the mechanical behaviour of $A K P$ under cyclic compressive loading. This work has shown that the damage of $A K P$ is most faster in cyclic compressive loading than in static compressive loading. On the another way, he has showed that the coupling of the number of loading cycles with the moisture content variations of the samples used, amplifies the latter's loss of mechanical performance under a variable load. The consideration of the gradual intensities on each loading cycle, made difficult the decoupling of the loading effects or the number of cycles on the behaviour of the studied samples. Nafa et al. (2003), on their side, worked on the damage to laminated timber beams submitted to cyclic torsional loading and showed also the effect of the load level on the behaviour and the durability of such structures. However, these papers related are not exhaustive to relate the mechanical behaviour of wood material under cyclic compressive loading but provide interesting information for understanding the impact of cyclic test in the wood behaviour in general. 
In addition, the coupling impact of cyclic loading and the variation of internal moisture content is not considered.

Moreover, when loading cyclically with a fairly low stress to a limited number of cyclic, anyway a densification occurs on the loaded material (Kutnar et al. 2008). During this densification, the cellular structure of wood is permanently modified, giving a material with new properties (Blomberg and Persson 2004, Kutnar and Šernek 2007). One of the main factors influencing the mechanical and physical behaviour of densified wood is the amount and type of cell collapse. We are interested here, in the effects of the environmental factors (moisture content changes) in the mechanical behaviour of three tropical woods during the process of densification. Our study therefore deals with the problem of the mechanical behaviour of tropical woods, subjected to the combined actions of cyclic compressive loadings and changes in the internal moisture content of wood. The objective is to understand the behaviour in cyclic compressive loading of three hardwood species, namely Okume, Iroko and Padouk on which, the database present a very weak panel of information's but which nevertheless represent the most exploited species of Gabon. The first part of this article presents the experimental setup used, as well as the protocol adopted to conduct our study. The second part presents the results obtained during the experimental tests, namely: the results on the impact of the loading combined with moisture variations on the mechanical behaviour of our three species.

\section{Material and methods}

\section{Wood specimens}

Okume, whose scientific name is Aucoumea klaineana Pierre (AKP), is a species of the Burseraceae family, which is endemic in Congo Basin, from the coast to a line passing through Okondja in eastern of Gabon and between Mitzic and Oyem in northern of Gabon, at Cameroon, Congo and over almost the whole Equatorial Guinea region (Medzegue 2007). AKP is a fastgrowing species that grows to a height of over $50 \mathrm{~m}$ and has a trunk diameter of up to $2 \mathrm{~m}$. In Gabon, it is used mainly for the manufacture of plywood, but also for structures such as sliced veneer and multi-ply plates (Martin and Vernay 2016, Gérard et al. 1998, Gérard et al. 2004).

The term "Iroko" refers to the two species of the genus Milicia in the Moraceae family: Milicia Excelsa $(M E)$ and Milicia Regia, which are very similar in morphology. Milicia excelsa is generally found on the African continent, from Guinea Bissau to Ethiopia, to Angola and Zimbabwe in a southerly direction; it is found particularly in Gabon. This tree reaches a maximum height of 45 to $50 \mathrm{~m}$ with a diameter of about $2.5 \mathrm{~m}$. It was first used in Gabon for the construction of canoes, then for structures such as glued laminated posts and carpentry (Martin and Vernay 2016, Daïnou et al. 2012, Gérard et al. 1998).

Padouk of Africa is the commercial name of Pterocarpus Soyauxii Taub (PS) of the Fabaceae family, a species found in central and west Africa but whose optimal growing area is Gabon and Cameroun. It is suitable for carving, cabinet making but also for hydraulic work in immersed marine environments and shipbuilding. Moreover, with its very interesting resonance properties (very pure metallic resonance), it is also perfectly suitable for the manufacture of organs, pianos or other musical instruments. Padouk trees reach a height of nearly $50 \mathrm{~m}$, with a diameter of about 60 to $100 \mathrm{~cm}$ and are free of branches up to about $30 \mathrm{~m}$ (Gérard et al. 1998, Martin and Vernay 2016, Gérard et al. 2004).

The choice of these three species is explained by the fact that in this study one of the objectives is to highlight the impact of density on the mechanical behaviour of wood. Hence the choice of a soft hardwood (Okoume), a medium hardwood (Iroko) and a heavy hardwood (Padouk) as classified by the cirad collection (Gérard et al. 1998 and 2004).

The Iroko and Padouk specimens used for our tests were taken in Libreville, from an open-air sawmill site, located between the Nkembo junction and the bus station interchange. On this site, a 3 $\mathrm{m}$ Padouk batten and a $2.5 \mathrm{~m}$ Iroko board were purchased for our work. As for the Okume samples, 
they were taken from the sample stock of the Laboratoire de Recherche et Valorisation du Matériau Bois (LaReVa Bois) at the Ecole Nationale des Eaux et Forêts (ENEF) of Gabon.

\section{Type of specimens used}

The dimensions of the wood specimens for the three species (Figure 1) are those given by the French standard NF EN 408 for a compression test, i.e. $20 \times 20 \times 60 \mathrm{~mm}^{3}$. A total of 90 test pieces were obtained, with 30 specimens per species.

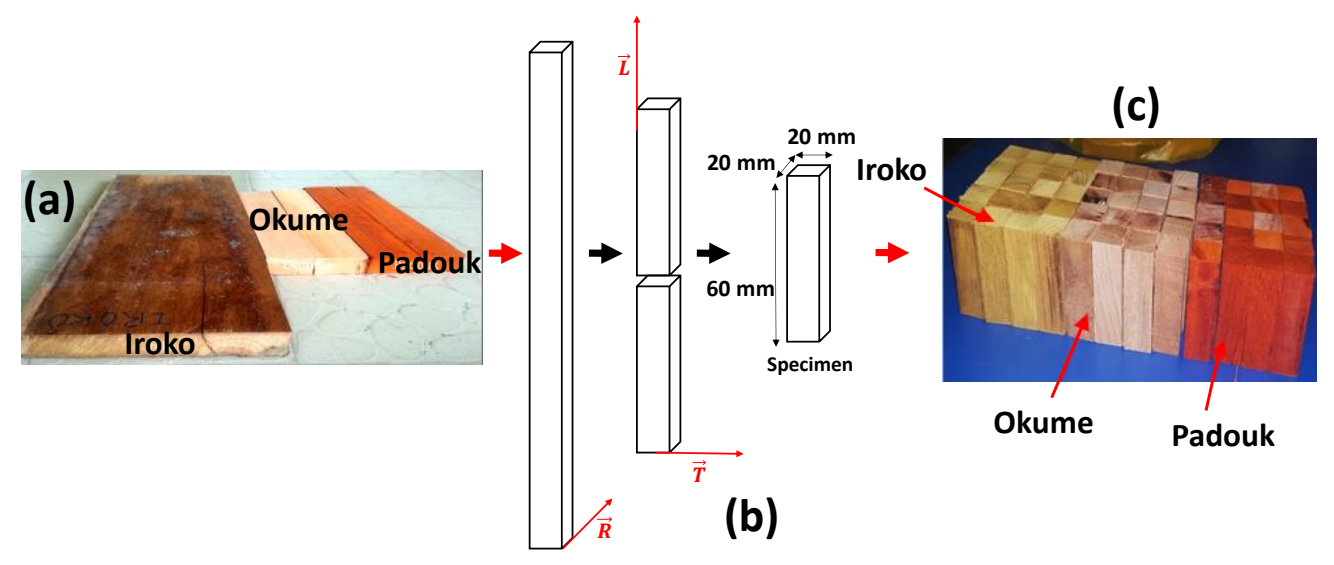

Figure 1. (a) Specimens of the species used, (b) Specimens cutting procedure; (c) specimens of the three topical species.

\section{Sample preparation}

The experimental device is compound of a "Universal testing machine" press, with a maximum load capacity of $100 \mathrm{kN}$ and a computer equipped with a data acquisition system managed by the Datum 5.0 software. To humidify the specimens, we used tanks filled with water, in which the specimens were immersed.

\section{Determining the intermediate dried weight $\left(M_{o i}\right)$}

Firstly, an intermediate dried weight $\left(M_{o i}\right)$ was determined for each group of species and for all the specimens (Table 1). This $M_{o i}$ is considered as the own dried weight of the specimen. Five specimens of each group of species were selected, for a total of 15 specimens and put in an oven set to be dried at a temperature of $103^{\circ} \mathrm{C}$, as presented by Odounga et al. (2018). Figure 2 shows the kinetic of dried weight changes in the oven drying of the species measured over the time until the weights stabilized. There is a very rapid decrease (loss of moisture in the specimens as described by Moutee 2006, Moyne and Martin 1982) in the weight of the specimens of all three species after 6 hours of drying. The dry weight is reached when a stabilization (linear part of the curves see Figure 2) of the sample weight is observed. 


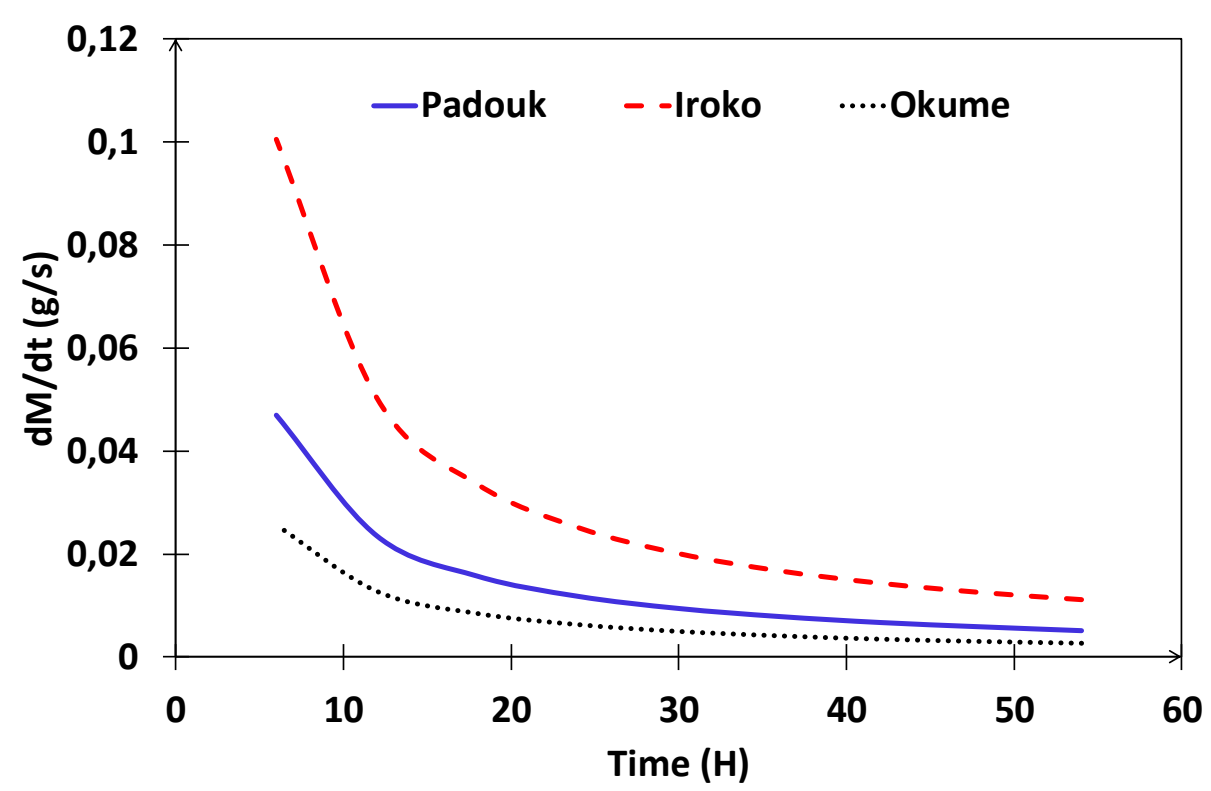

Figure 2. Changes to the average mass of the three species up to stabilisation

The weight value of the specimen, after it has stabilised in the oven, represents the own dried weight of the specimen. Finally, the intermediate dried weight $\left(M_{o i}\right)$ of each species, which will be used to determine the MC, was obtained by calculated the average dried weight of the five specimens using the following Equation:

$$
\text { Moi } \quad\left(\sum_{j=1}^{5} M o_{j}\right) / 5
$$

The results obtained from this calculation are shown in table 1 below.

Table 1. Means of intermediate anhydrous weight of the specimens obtained (mean \pm SD)

\begin{tabular}{lccc}
\hline Specimens & Okume & Iroko & Padouk \\
\hline \hline $\mathrm{M}_{\mathrm{oi}}(\mathrm{g})$ & $9.91 \pm 0.29$ & $9.66 \pm 0.39$ & $15.89 \pm 1.37$ \\
\hline
\end{tabular}

\section{Determining the moisture content (MC) of the specimen}

Eight different levels of Moisture Content (MC) for the study of the specimens were arrested: 10\%, $15 \%, 25 \%, 30 \%, 35 \%, 40 \%, 60 \%$ and $90 \%$. To have these different levels of MC, the specimens were firstly put in tanks filled with water, for their saturation, during six weeks for the $A K P$ and $M E$ specimens and eight weeks for the PS specimens. Then, the results of the $M_{o i}$ (see Table 1) calculated for each species were used to determine the moisture content (MC) of each specimen studied by coupling the empirical method of the determination of the MC. The method consists by drying naturally the specimens saturated until the corresponding MC found. In this case, the intermediate dried weight $\left(M_{o i}\right)$ for each species calculated, is considered as the dried weight of the

$$
\operatorname{MC}(\%)=\left[\left(M_{H}-M_{0 i}\right) / M_{0 i}\right] \times 100
$$

specimen tested, then for each species the following equation is used:

Where: $\mathrm{M}_{\mathrm{H}}$ is the weight of the specimen at humidity $H$ and $M_{o i}$ the intermediate dried weight for each species. 


\section{Results and discussions}

\section{Static compression loading}

Static compression tests were first performed on 5 specimens for each species to mechanically characterise them. Thus, by using these tests, we could determine the maximum stress at the collapse point and the module of elasticity (MOE) of each species for the static compressive test. Figure 3 shows the stress-strain relationships taken from the compressive static tests performed on the specimens of the species of $A K P$ (Figure 3a), $M E$ (Figure $3 b$ ) and $P S$ (Figure 3c) at $12 \pm 2 \% \mathrm{MC}$. According to the literature (Guitard and Gachet 2004, Manfoumbi Boussougou et al. 2014, Moutee 2006) it is known that two main sections can be identified on these stress-strain curves, i.e.: a linear part corresponding to the elastic zone and a parabolic shaped part corresponding to the plastic zone (Figure 3). The analysis of the different curves obtained during these static compression tests enabled us to determine the mechanical properties of our three species.
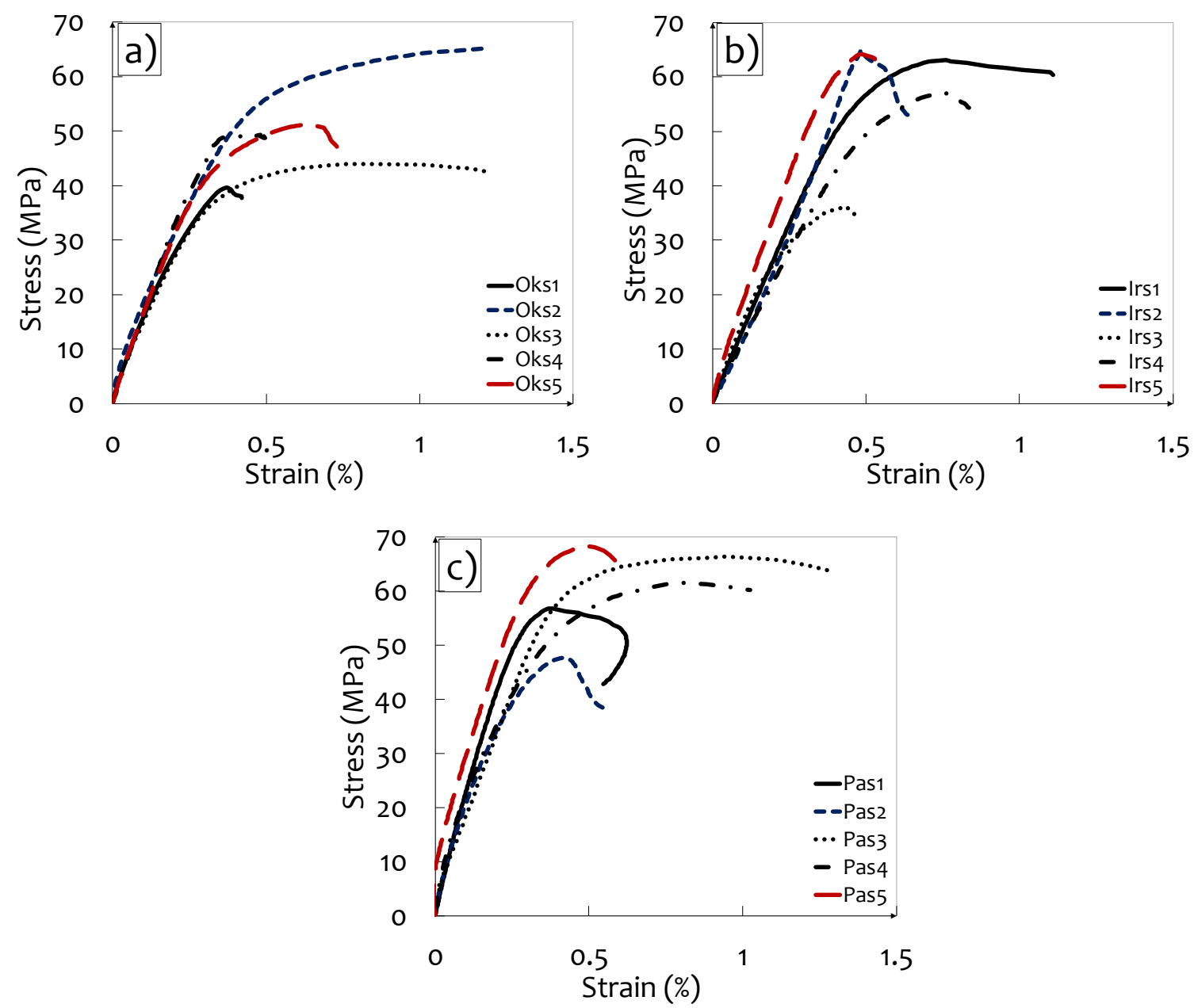

Figure 3. Typical stress-strain curves of compressive static tests performed on the specimens: (a) Okume, (b) Iroko and (c) Padouk

Tables 2 shows the main physical and mechanical results obtained after the compressive static test on the specimens of the three species studied. The values presented in this table, represent the mean \pm standard deviation for each parameter calculated. 
Table 2. Physical and mechanical parameters of three species

\begin{tabular}{|c|c|c|c|c|c|c|c|c|}
\hline \multirow{2}{*}{ Species } & \multicolumn{3}{|c|}{ Size (mm) } & \multirow{2}{*}{$\mathrm{MC}(\%)$} & \multirow{2}{*}{$\mathrm{M}(\mathrm{g})$} & \multirow{2}{*}{$\rho\left(\mathrm{g} / \mathrm{cm}^{3}\right)$} & \multirow{2}{*}{$\begin{array}{l}\mathrm{MOE} \\
(\mathrm{GPa})\end{array}$} & \multirow{2}{*}{$\mathrm{MS}(\mathrm{MPa})$} \\
\hline & $\mathrm{L}$ & $\mathrm{e}_{\text {moy }}$ & $\mathrm{h}_{\text {moy }}$ & & & & & \\
\hline$A K P$ & $61.32 \pm 0.40$ & $19.83 \pm 0$ & $19.56 \pm 0.16$ & $12.46 \pm 0.26$ & $11.14 \pm 0.03$ & $0.46 \pm$ & $12.77 \pm 2.50$ & $49.35 \pm 9.52$ \\
\hline$M E$ & $60,84 \pm 0.06$ & $19.49 \pm$ & $19.56 \pm$ & 12.2 & $12.9 \pm 0.07$ & $0.56 \pm 0.01$ & $13.09 \pm 1.57$ & $57.10 \pm 1.21$ \\
\hline$P S$ & $61.45 \pm 0.31$ & $19.84 \pm 0.33$ & $20.11 \pm 0.42$ & $12.12 \pm 0.23$ & $17.83 \pm 0.034$ & $0.72 \pm 0.02$ & $17.48 \pm 2.30$ & $60.08 \pm 8.32$ \\
\hline
\end{tabular}

As expected, we see in Table 2 that Padouk is the species with the highest maximum stress at break point in static compression, followed respectively by Iroko and Okume. This is easily explained by their respective densities. Padouk being the densest species with $0.72 \pm 0.02$ of density, its maximum stress at break point is therefore the highest, followed respectively by Iroko and Okume (with respective densities of $0.56 \pm 0.01$ and $0.46 \pm 0.01$ ). This observation is also valid for the MOE, Padouk still having the highest MOE value, followed by Iroko and Okume. he MOE values obtained experimentally differ from those obtained in the literature (Gérard et al. 2004, Gérard et al. 1998) by 23\%, 2\% and 7\% respectively for the Okume, Iroko and Padouk specimens. Likewise, the maximum stresses differ by $27 \%, 5 \%$ and $8 \%$ respectively for the Okume, Iroko and Padouk specimens. These differences between our experimental values and those from the literature can be explained in part by the origin of the species from which the specimens were taken. Indeed, several studies have shown that depending on their biological origins, the characteristics of wood materials can vary between species, within the same species and within the same tree (Medzegue et al. 2007, Pâques 1996, Guitard and Gachet 2004, Almeida 2006, Charron et al. 2003). An investigation on the results obtain in this part, for the two specie Okume and Iroko, shows a difference near to $18 \%$ of their respective mean density which is weak compared at that showed in the literature ( $31 \%$ for the density between the two specie). The main explanation could be the origin of the region where the species studied were cut or the times of the log exposure in the lumberyard.

\section{Cyclic compression loading}

For each species studied, five compression loading cycles parallel to the fibres at a constant stress level, i.e. $10 \%$ of the maximum stress at the Okume break point, were carried out. This maximal loading was arrested because one of the goal of this study is to perform the test, for each specimen, in the elastic domain of the material. The reason of the choice of this loading is that compared to the two others species studied (Iroko and Padouk), Okume presents by taking into account the literature investigations and our results the weakest physical and mechanical characteristics. Figure 4 shows the general behaviour of the stress-strain curves for the Okume, Iroko and Padouk specimens obtained after the cyclic compression tests, at 10\% of MC (Fig. 6a), 25\% of MC (Figure 4b), 30\% of MC (Figure 4c) and 60\% of MC (Figure 4d). 

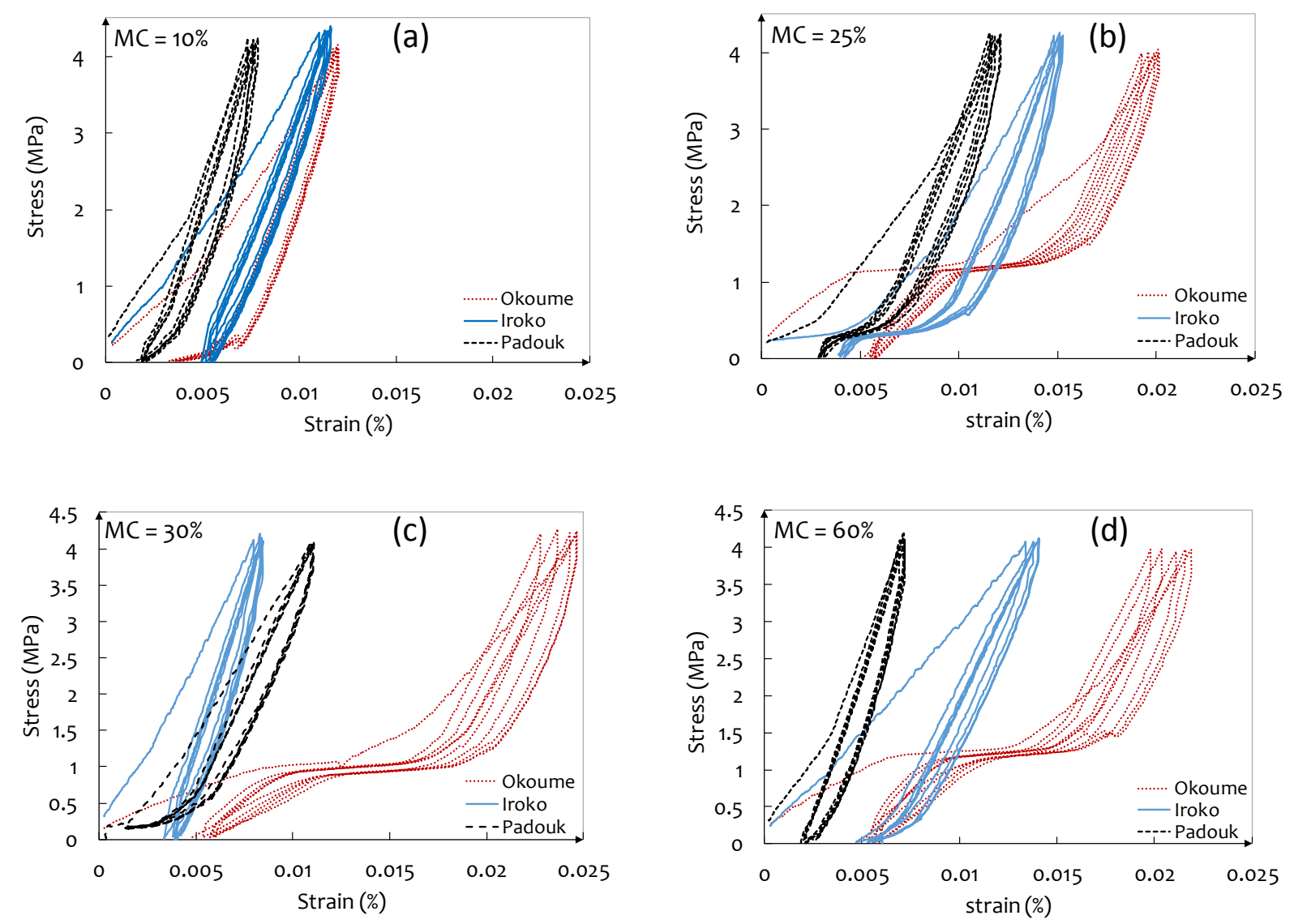

Figure 4. Typical stress-strain curves of cyclic compression specimens

The actual discussion will essentially focus, on these four level of MC. This choice is justifying by the fact that, by taking into account the literature (Odounga et al. 2018), we can consider two domains of the hygroscopic behaviour of wood: (i) the mechanical behaviour of the wood with MC located before the FSP and (ii) the mechanical behaviour of the wood with the MC located after FSP. It appears at each MC level of the specimens, that for the three species, the loading path differs from the unloading path. In other words, Okume, Iroko and Padouk present hysteresis at unloading during the different cycles. These hysteresis phenomena can be explained by the fact that our materials are not perfectly elastic (Fozao et al. 2014). We also observe on these curves (Figure 4) that after the first loading cycle, the strain does not return to its initial level after the unloading path. This highlights the existence of the residual permanent strain that appeared in the first loading cycle, despite the low intensity of the force used (Pambou Nziengui et al. 2017). However, the residual permanent strain observed during the first loading cycle remains constant in the following cycles. Everything happens as if the specimen had adapted to the stress exerted.

\section{Impact of loading combined with variations in moisture content (MC) on strain amplitude}

The histograms in Figure 5 show the change in deformation of the specimen after each cycle at different MC levels. 
(a)

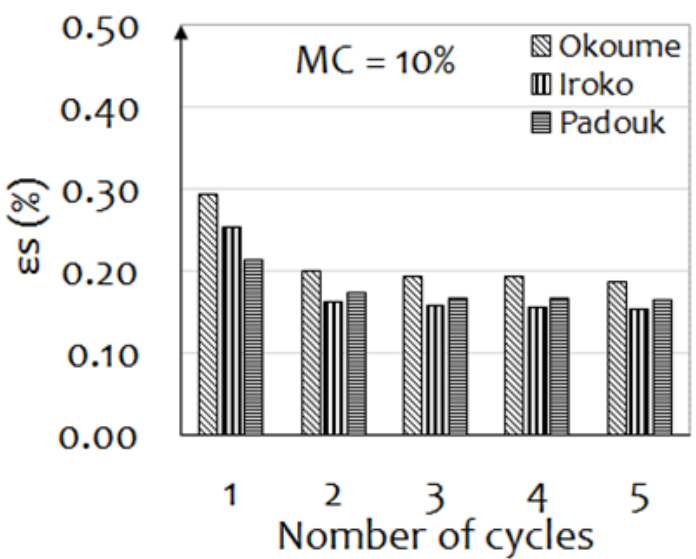

(c)

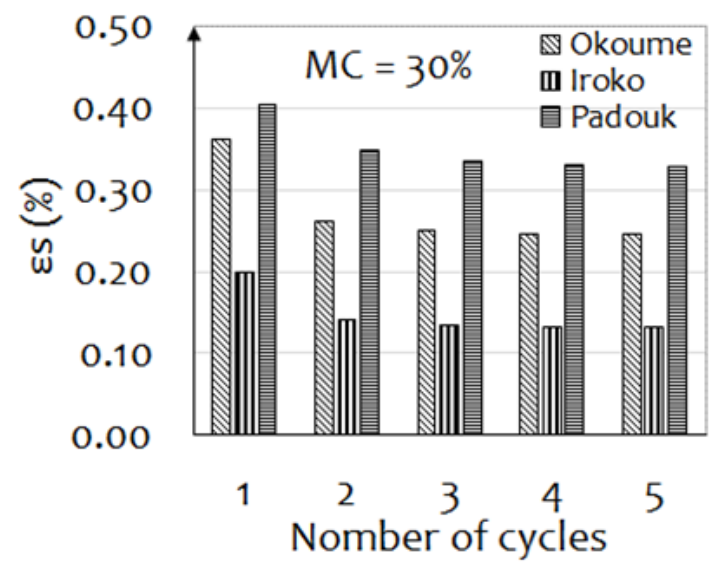

(b)

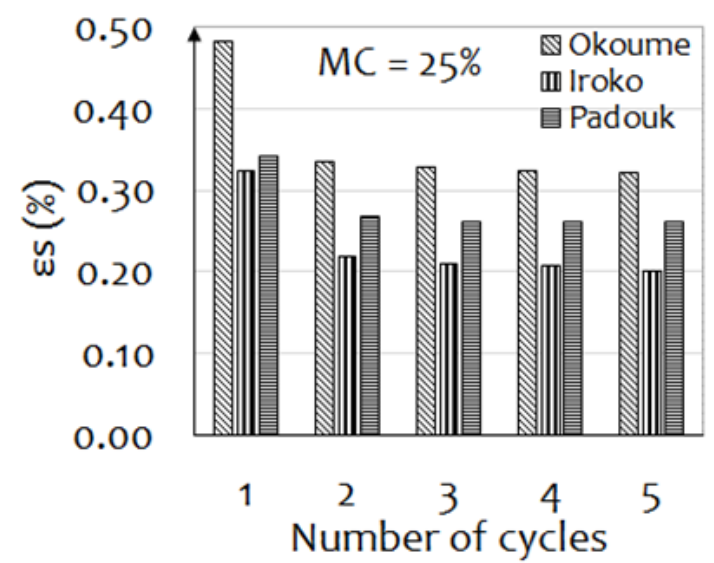

(d)

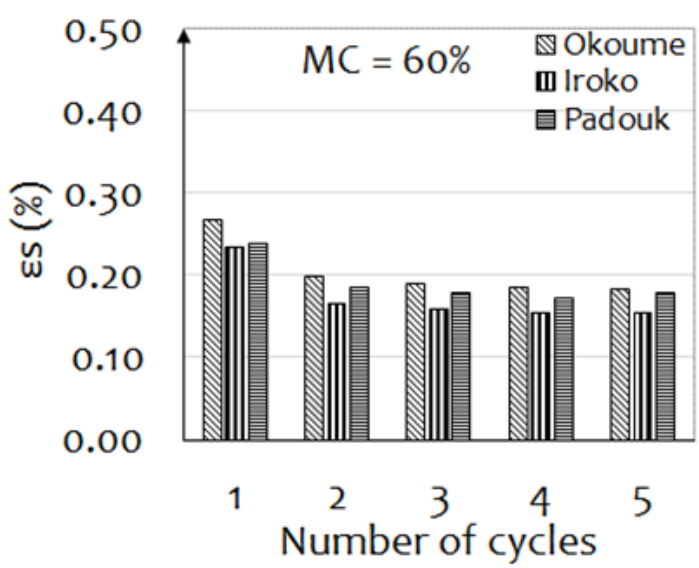

Figure 5. Comparison of the amplitudes of strain of the five loading cycles on the Okoume, Iroko and Padouk specimens

A coupling and a closer observation of the stress-strain curves in Figure 4 and the histograms of Figure 5 shows a decrease in the strain amplitude $\left(\varepsilon_{\mathrm{s}}\right)$ with the number of loading cycles. Between the first and fifth loading cycles, a regression of $\varepsilon_{\mathrm{s}}$ of $0.11 \%, 0.10 \%$ and $0.05 \%$ for the Okume, Iroko and Padouk respectively at $10 \%$ moisture (Figure 5a). At $25 \%$ moisture (Figure 5b), the regression is $0.16 \%, 0.12 \%$ and $0.08 \%$ for the Okume, Iroko and Padouk respectively. At $30 \%$ moisture (Figure 5c), it is $0.12 \%, 0.07 \%$ and $0.08 \%$ for the Okume, Iroko and Padouk respectively. Finally, at $60 \%$ moisture (Figure 5d), the regression is $0.08 \%$ for the Okume and Iroko, $0.06 \%$ for the Padouk. In other words, there is specimen strain during the loading cycle despite the low intensity of the load used. This regression of $\varepsilon_{\mathrm{s}}$ can be explained by the densification phenomenon that appears during the different loading cycles (Kutnar et al. 2015, Blomberg and Persson 2004). Indeed, just as in the drying process, the cell wall is compacted and the mass of the ligneous substance in a given volume increases during the different loading cycles (Kutnar et al. 2015, Segovia et al. 2013). This has the consequence of stiffening the specimens and thus reducing the strain in the following cycles. Also, the change in behaviour between the Iroko and Padouk specimens observed in the second loading cycle (Figures $4 a, 4 b, 4 c, 4 d$ ) suggests that the densification observed occurs earlier in the Padouk specimens compared to the Iroko specimens. This regression of the strain amplitude can also be explained by the accommodation effect (Nguyen 2014). Indeed, after the first loading cycle, we have the specimen adapts to the stress imposed which can cause the stabilization of the strain observed in the following cycles. 
For each cycle, we have plotted the changes to the strain amplitude with different moisture levels. Figure 6 shows the change in $\varepsilon_{\mathrm{s}}$ at each loading cycle as a function of each moisture level for the specimens tested.
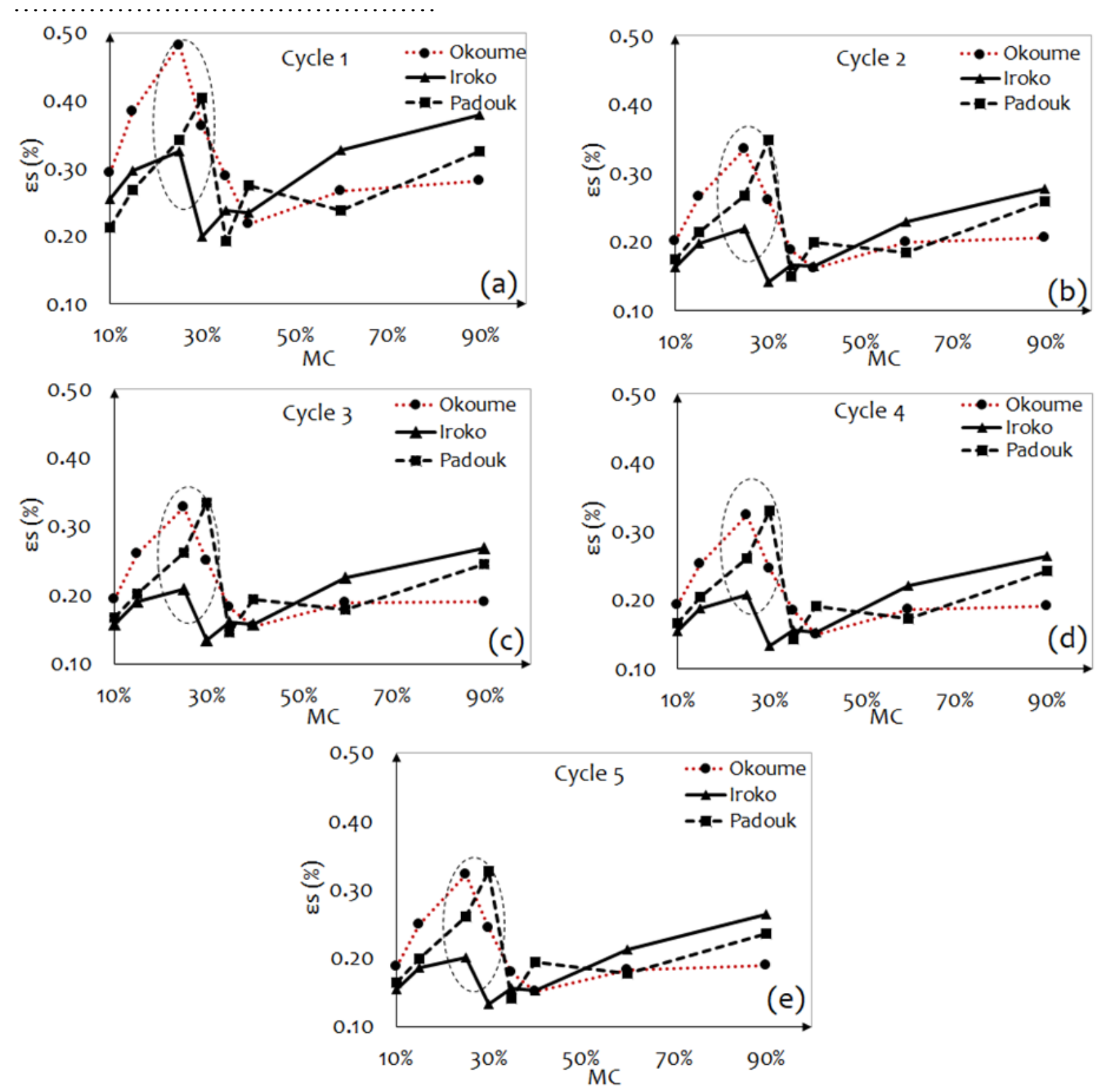

Figure 6. Effects on the strain amplitude $\left(\varepsilon_{\mathrm{s}}\right)$ for Iroko, Okume and Padouk specimens by the moisture levels. The ellipses represent the zone of the hygroscopic domain of our three species.

In general, for the three species, we observed an increase in strain amplitude at each cycle up to a certain moisture level close to $30 \%$ (Figures 6a, 6b, 6c, 6d, and 6e). This increase in $\varepsilon_{\mathrm{s}}$ could be explain by the rise of moisture content which lead the softening of the test pieces. Indeed, the change in moisture content deeply affects the balance of the elastic constants of the wood, especially where the moisture content is in the hygroscopic domain (Dinh 2011, Gerhards 1982, Moutee et al. 2005). Thus, the increase in humidity causes a decrease in the rigidity of the specimens. This decrease in the rigidity has the effect of increasing the specimen strains during loading. However, Figure 6 also shows that the increase in strain as with moisture levels rise is not continuous. There is a discontinuity due to the FSP, the point from which the MC level becomes too large to judge the effect of the stress. It is therefore more than likely that the area where this change of variation occurs matches the FSP domain of our three species. The ellipse observed on each of 
the curves in Figure 6 thus shows the FSP domain. Finally, it should be said that these results are fairly consistent with the data in the literature, which indicates FSP at around 30\%, 25\% and 21\% moisture respectively for the Okume, Iroko and Padouk specimens (Gérard et al. 2004, Gérard et al. 1998, Medzegue et al. 2007).

\section{Conclusion}

The objective of this study was to perform a comparative study to highlight the impact of cyclic compressive loading combined with variations in moisture content, on the mechanical behaviour of three tropical species. The species chosen including a soft hardwood (Okume), a medium hardwood (Iroko) and a heavy hardwood (Padouk). The dimensions of the wood specimens for the three species are those set down in French standard NF EN 408 for a compression test, i.e. $20 \times 20 \times 60$ $\mathrm{mm}$.

The cyclic tests carried out, in the elastic domain made it possible, firstly, to highlight the emergence of a constant residual permanent strain in the specimens of the three species during the different loading cycles. In other words, the strains generated during the loading are not fully absorbed when unloaded. Hysteresis is then observed during unloading. In the other way, these cyclic tests carried out with a constant load level and at different moisture levels made it possible to show that there is a densification (or a crushing) of the specimens which occurs with the loading cycles, thus causing the regression of the strain. In addition, they show that the crushing observed is faster respectively from the densest species (Padouk) to the least dense species (Iroko and Okume respectively) in the dry state (here at $10 \%$ of $\mathrm{MC}$ ). This trend tends to change in the FSP domain where the impact of moisture content coupled with loading becomes less and less important.

For future work, in order to better evaluate the resistance of our three species subjected to cyclic stress in compression; it would be interesting to increase the number of loading cycles. It would be interesting to also perform fatigue tests in compression. It would also be interesting to perform cyclic bending tests to understand the behaviour of structures such as bridges. The results obtained in this section highlight also the necessity to sampling directly in the forest our specimens studied.

\section{Acknowledgments}

The authors wish to thank the Network of Forestry and Environmental Training Institutions of Central Africa (RIFFEAC) for the implementation of the Wood Science Master of the Ecole Nationale des Eaux et Forêts (ENEF - GABON) as well as the PEPS project CNRS "RUMO" and the Auvergne Rhône-Alpes Region (AURA) for financial support under the SCUSI project.

\section{References}

Almeida, G., 2006. 'Influence de la structure du bois sur ses propriétés physico-mécaniques à des teneurs en humidité élevées', Doctoral dissertation, Univerté de Laval.

Blomberg, J. and Persson, B., 2004. 'Plastic deformation in small clear pieces of Scots pine (Pinus sylvestris) during densification with the CaLignum process', Journal of Wood Science, 50(4), 307-314.

Charron, S., Jourez, B., Marchal, M. and Hébert, J., 2003. 'Etude comparative des caractéristiques physiques et mécaniques du bois des mélèzes d'Europe (Larix decidua Mill.), du Japon (Larix kaempferi (Lambert) Carr.) et de leur hybride (Larix x eurolepis Henry)', Biotechnologie, Agronomie, Société et Environnement, 7(1), 5-16.

Daïnou, K., Doucet, J.-L., Sinsin, B. and Mahy, G., 2012. 'Identité et écologie des espèces forestières commerciales d'Afrique centrale: le cas de Milicia spp.(synthèse bibliographique)', Biotechnologie, Agronomie, Société et Environnement, 16(2), 229-241.

Dinh, A. T., 2011. 'Linear elastic and non-linear behaviour of wood according to its structure', unpublished thesis AgroParisTech.

Ebrahimzadeh, P. and Kubat, D., 1993. 'Effects of humidity changes on damping and stress relaxation in wood', Journal of materials science, 28(20), 5668-5674. 
Eurocode 1, Association Francaise de Normalisation., 2005. 'Eurocode 1: Actions sur les structures-Partie 1-4: Actions générales-Actions du vent, EN 1991-1-4.

Eurocode 5, Association Francaise de Normalisation., 2005. '5: Conception et calcul des structures en bois-Partie 1-1: Généralités-Règles communes et règles pour les bâtiments', Norme française NF EN 1995-1, 1.

Gérard, J., Beauchêne, J., Fouquet, D., Guibal, D., Langbour, P., Thévenon, M.-F., Thibaut, A. and Vernay, M., 2004. ' TROPIX 5.0 : caractéristiques technologiques de 215 essences tropicales, email to [accessed none].

Gérard, J., Edi Kouassi, A., Daigremont, C., Détienne, P., Fouquet, D. and Vernay, M., 1998. 'Synthèse sur les caractéristiques technologiques de référence des principaux bois commerciaux africains'. Série FORAFRI, Montpellier, France: CIRAD-Forêt.

Gerhards, C. C., 1982. 'Effect of moisture content and temperature on the mechanical properties of wood: an analysis of immediate effects', Wood and Fiber Science, 14(1), 4-36.

Guitard, D. and Gachet, C., 2004. 'Paramètres structuraux et/ou ultrastructuraux facteurs de la variabilité intra-arbre de l'anisotropie élastique du bois'. Ann. For. Sci., 61(2), 129-139.

Kitek Kuzman, M. and Sandberg, D., 2018. 'Produits d'Ingénierie en Bois pour l'Architecture Contemporaine-Cas d' étude'.

Kutnar, A., Kamke, F. A. and Sernek, M., 2008. 'The mechanical properties of densified VTC wood relevant for structural composites', Holz als Roh-und Werkstoff, 66(6), 439-446.

Kutnar, A. and Šernek, M., 2007. 'Densification of wood'. Zbornik gozdarstva in lesarstva, (82), 53-62.

Kutnar, L., Eler, K. and Marinsek, A., 2015. 'Effects of different silvicultural measures on plant diversity - the case of the Illyrian Fagus sylvatica habitat type (Natura 2000)'. iForest - Biogeosciences and Forestry, 9(2), 318-324.

Lenth, C. A. and Kamke, F. A., 2001. 'Moisture dependent softening behavior of wood'. Wood and Fiber Science, 33(3), 492-507.

Manfoumbi Boussougou, N., Nguyen, T. A., Angellier, N., Dubois, F., Ulmet, L. and Sauvat, N., 2014. 'Experimental and numerical aspects in diffusion process characterization in tropical species', European Journal of Environmental and Civil Engineering, 18(9), 963-982.

Mårtensson, A. and Thelandersson, S., 1990. 'Effect of moisture and mechanical loading on wooden materials'. Wood Science and Technology, 24(3), 247-261.

Martin, P. and Vernay, M. (2016) Guide d'utilisation des bois africains éco-certifiés en Europe,

Medzegue, M. J., 2007. 'Etude comparative des bois d'Okoumé (Aucoumea Klaineana P.) issus des plantations et de la forêt naturelle: anatomie, durabilité naturelle'. Doctoral Dissertation, Université de Bordeaux 1.

Medzegue, M. J., Grelier, S., M’Batchi, B., Nziengui, M. and Stokes, A., 2007. 'Radial growth and characterization of juvenile and adult wood in plantation grown okoumé (Aucoumea klaineana Pierre) from Gabon'. Annals of Forest Science, 64(8), 815-824.

Moutee, M., 2006. 'Modélisation du comportement mécanique du bois au cours du séchage'. Doctoral Dissertation, Université de Laval.

Moutee, M., Fafard, M., Fortin, Y. and Laghdir, A., 2005. 'Modeling the creep behavior of wood cantilever loaded at free end during drying'. Wood and Fiber Science, 37(3), 521-534.

Moyne, C. and Martin, M., 1982. 'Etude experimentale du transfert simultane de chaleur et de masse au cours du sechage par contact sous vide d'un bois resineux'. International Journal of Heat and Mass Transfer, 25(12), 1839-1848.

Mukudai, J. and Yata, S., 1986. 'Modeling and simulation of viscoelastic behavior (tensile strain) of wood under moisture change'. Wood Science and Technology, 20(4), 335-348. 
Nafa, Z. and Araar, M., 2003. 'Applied data for modeling the behavior in cyclic torsion of beams in glued-laminated wood: influence of amplitude'. Journal of Wood Science, 49(1), 0036-0041.

Natterer, J., 2004. 'Construction en bois: matériau, technologie et dimensionnement'. PPUR presses polytechniques.

Navi, P. and Girardet, F., 2000. 'Effects of thermo-hydro-mechanical treatment on the structure and properties of wood'. Holzforschung, 54(3), 287-293.

Nguyen, S. T. T., 2014. 'Experimental characterization and thermo-mechanical modeling of cyclic behavior of polyethylene'. Doctoral Dissertation, ISAE-ENSMA Ecole Nationale Supérieure de Mécanique et d'Aérotechique - Poitiers.

Odounga, B., Moutou Pitti, R., Toussaint, E. and Grédiac, M., 2018. 'Mode I fracture of tropical woods using grid method'. Theoretical and Applied Fracture Mechanics, 95, 1-17.

Pambou Nziengui, C. F., Ikogou, S. and Moutou Pitti, R. 2017. 'Impact of cyclic compressive loading and moisture content on the mechanical behavior of Aucoumea Klaineana Pierre'. Wood Material Science \& Engineering, 13(4), 190-196.

Pâques, L., 1996. 'Variabilité naturelle du mélèze. I. Mélèze d'Europe : bilan de 34 ans de test comparatif de provenances'. Ann. For. Sci., 53(1), 51-67.

Redman, A. L., Bailleres, H., Turner, I. and Perré, P. 2016. 'Characterisation of wood--water relationships and transverse anatomy and their relationship to drying degrade'. Wood Science and Technology, 50(4), 739-757.

Segovia, F., Blanchet, P., Laghdir, A. and Cloutier, A. 2013. 'Mechanical behaviour of sugar maple in cantilever bending under constant and variable relative humidity conditions', International Wood Products Journal, 4(4), 225-231.

Stevens, M., 1990. 'Les atouts écologiques du bois comme materiau de construction'. Silva Gandavensis, 55. 